\title{
Superficial Scald of 'Granny Smith' Apples is Expressed as a Typical Chilling Injury
}

\author{
Christopher B. Watkins ${ }^{1}$, William J. Bramlage ${ }^{2}$, and Belinda A. Cregoe \\ The Horticulture and Food Research Institute of New Zealand, Mt. Albert Research Centre, Private Bag \\ 92169, Auckland, New Zealand
}

Additional index words. Malus domestics, ofarnesene, breakdown, conjugated trienes, coreflush, ethylene, warming, diphenylamine

\begin{abstract}
To examine the hypothesis that superficial scald of apple (Malus domestics Borkh.) is a chilling injury, 'Granny Smith' apples were stored at temperatures ranging from 0 to $20 \mathrm{C}$, temperature-conditioned before storage, and warmed during storage. Fruit stored at 0 or $4 \mathrm{C}$ developed supeficial scald. At $10 \mathrm{C}$, surface defects occurred but they were not typical symptoms of scald, and at 15 or $20 \mathrm{C}$ no symptoms developed. Accumulation of $\alpha$-l faroesene and conjugated trienes in fruit peel correlated with increasing ethylene production, which was greater at higher temperatures. However, concentrations of conjugated trienes were highest at 0 and $4 \mathrm{C}$. When fruit were kept at $10 \mathrm{C}$ for 5 or 10 days before storage, scald development after storage was not reduced. An interruption of $0 \mathrm{C}$ storage with a single warming period at 10 or $20 \mathrm{C}$ reduced scald development after 25 weeks of storage, maximum reduction occurring when fruit were warmed for 3 to 5 days at $20 \mathrm{C}$ after 1 to 4 weeks at $0 \mathrm{C}$. Amelioration of scald declined as time at $\mathrm{OC}$ before warming increased. Diphenylamine application after the same intervals at $\mathrm{OC}$, instead of warming, also was less beneficial as time before treatment increased. $\alpha$-Farnesene and conjugated trienes increased during warming, but at the end of storage (when scald was developing) the conjugated triene concentrations in peel were reduced in fruit that had been warmed. Warming slightly increased yellowing, softening, and greasiness of fruit after storage, We conclude that chilling induced superficial scald on 'Granny Smith' apples.
\end{abstract}

Superficial scald is a physiological disorder of certain apple and pear cultivars that develops during prolonged low-temperature storage. Typically, early-harvested and less-mature fruit are most susceptible, but scald also may develop on fully mature fruit. The disorder is manifest as browning of the skin as a result of damage to the hypodermal cells (Bain and Mercer, 1963). Scald development is widely believed to result from production of $\alpha$-famesene and its autoxidation to conjugated trienes (Anet, 1972; Du and Bramlage, 1994). Generally, correlations between conjugated triene concentrations and scald occurrence are strong (Anet and Coggiola, 1974; Huelin and Coggiola, 1970b; Meir and Bramlage, 1988; Scott et al., 1980), but those between $x$-tfamesene and scald are variable (Anet, 1972; Huelin and Coggiola, 1968; Meigh and Filmer, 1969; Meir and Bramlage, 1988). $\alpha$-'Famesene typically increases rapidly during storage and then declines during the time of scald development, and its accumulation appears to be concomitant with rising ethylene production (Watkins et al., 1993).

Chilling injury generally results from exposure of tropical or subtropical plants to temperatures below 10 to 15C (Saltveit and Morris, 1990). However, Bramlage and Meir (1990) have argued that temperate plants, while resistant to chilling damage, are not immune to it. These fruit have the inherent potential to develop symptoms of chilling injury under rigorous conditions. Apples are a temperate crop and scald occurs after long-term cold storage. Early reports stated that optimum temperature for scald development was $15 \mathrm{C}$, and that in some cultivars it occurred at $25 \mathrm{C}$, but

Receivedforpublication11 Apr. 1994. Accepted for publication 8 Aug. 1994. This research was supported in part by the Council for International Exchange of Scholars,theNewZealandApple and Pear Marketing Board, and The New Zealand Foundation for Research, Science and Technology. We thank Tim Bartley and Suzanne Reid for excellent technical assistance, and Sarah Weis for statistical analyses of the data. The cost of publishing this paper was defrayed in part by the payment of page charges. Under postal regulations, this paper therefore must be hereby marked advertisement solely to indicate this fact.

'Presentaddress: Dept. of Fruit and Vegetable Science, Cornell Univ., Ithaca, NY 14853.

${ }^{2}$ VisitingFulbrightFellow.Permanentaddress:Dept.ofPlantandSoilSciences,Univ. of Massachusetts, Amherst, MA 01003. never at 30C (Brooks and Cooley, 1917; Brooks et al., 1919). Smock (1961 ) also reported scald development on fruit in polyethylene bags at $21 \mathrm{C}$. However, most studies repot-t scald at temperatures no higher than 15C. Martin and Lewis (1961) and Huelin and Coggiola ( 1970b) showed that, while scald developed earlier at higher storage temperatures (3.5 and 15C), given sufficient time it was more severe when fruit were stored at lower temperatures $(-1.5$ and $5 \mathrm{C})$. This time-temperature relationship for symptom expression is typical of a chilling disorder (Saltveit and Morris, 1990).

Other features of scald development support the suggestion that it is a chilling injury. Keeping fruit at warn-t temperatures after harvest (conditioning) before imposing cold treatments sometimes reduces scald (Meigh, 1970; Padfield, 1949), and prestorage heat treatment of 38C for 4 days delayed scald development on 'Granny Smith' apples at 0C (Lurie et al., 1991). The disorder can be alleviated by antioxidants such as diphenylamine (DPA) (Huelin and Coggiola, 1968; Lau, 1990), controlled- atmosphere storage (Chen et al., 1985; Lau, 1990), and intermittent warming (Kidd and West, 1935; Smith, 1959), all methods that inhibit development of chilling injury in fruit (Wang, 1993).

Superficial scald is a serious problem on stored apples, and to develop strategies for protection it is necessary to define clearly its relationship with storage temperature. To do this we have reexamined effects of storage temperature, conditioning, and warming of fruit during storage on scald development.

\section{Materials and Methods}

Source of fruit. 'Granny Smith' apples were harvested from randomly selected groups of three trees at the Havelock North Research Orchard to provide five replicate lots of fruit for each experiment. The fruit were transported overnight to Auckland, where fruit quality was evaluated and experimental treatments imposed.

Effects of storage temperatures. Fruit were stored at 0,4,10,15, and $20 \mathrm{C}$ for $30,20,10,7.5$, and 5 weeks, respectively. These 

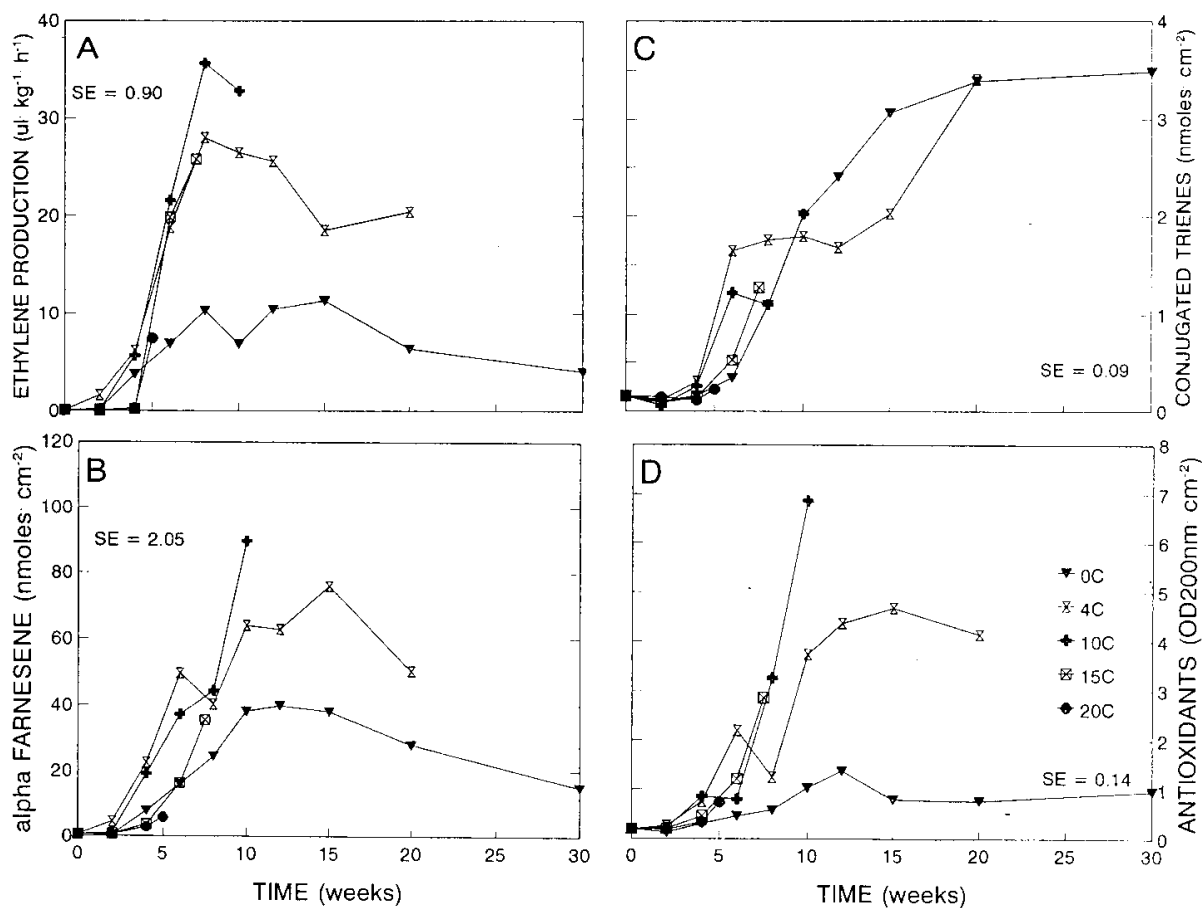

Fig. 1. Ethylene production (A) and accumulations of $\quad \alpha-1$ farnesene (B), conjugated trienes (C), and antioxidants (D) in peel of 'Granny Smith' apples kept at different temperatures.

intervals were designed to allow all fruit to reach the same stage of ripening and senescence at the different temperatures. At the start

Table 1. Color measurements of 'Granny Smith' apples at the end of storage at different temperatures and times.

$\begin{array}{lccc}\begin{array}{l}\text { Temp } \\ \left({ }^{\circ} \mathrm{c}\right)\end{array} & \begin{array}{c}\text { Time } \\ (\text { weeks })\end{array} & \mathrm{L}^{*} & \mathrm{a}^{*} / \mathrm{b}^{*} \\ 0 & 30 & 57 \mathrm{c}^{\mathrm{z}} & -0.45 \mathrm{a} \\ 4 & 20 & 65 \mathrm{~b} & -0.38 \mathrm{C} \\ 10 & 10 & 66 \mathrm{~b} & -0.41 \mathrm{~b} \\ 15 & 7.5 & 73 \mathrm{a} & -0.33 \mathrm{~d} \\ 20 & 5 & 66 \mathrm{~b} & -0.40 \mathrm{bc}\end{array}$

${ }^{z}$ Means in a column not followed by a common letter are significantly different at $P \leq 0.05$, using Duncan's new multiple range test. of the experiment (12 Apr. 1991) and at regular intervals during storage, ethylene production and background color of 10-fruit samples per replicate were measured before extraction with hexane for measurement of $\alpha$-famesene, conjugated trienes, and antioxidant concentrations in the peel. At the end of storage at each temperature, 60 fruit per replicate were transferred to $20 \mathrm{C}$ for 7 days, after which 10 were extracted in hexane and 50 were evaluated visually for scald.

Effects of warming. Preclimacteric fruit were harvested on 4 Apr. 1991. On the following day and after 2 to 12 weeks at 0C, samples either were kept at $20 \mathrm{C}$ for 5 days or treated for 1 min with $1 \mathrm{~g} \cdot$ liter $^{-1} \mathrm{DPA}$, and then returned to 0C. Each treatment was warmed only once and the DPA-treated samples were not warmed. All fruit were stored for a total of 25 weeks at 0C. Each replicate consisted of 120 fruit: 10 each for measuring background color,

Table 2. Ethylene production and $\alpha$-farnesene, conjugated triene, and antioxidant concentrations in 'Granny Smith' apples removed at different intervals from $0 \mathrm{C}$ storage (0 days) and kept at $20 \mathrm{C}$ for 5 days.

\begin{tabular}{|c|c|c|c|c|c|c|c|c|}
\hline $\begin{array}{l}\text { Time of removal } \\
\text { from cold storage }\end{array}$ & \multicolumn{2}{|c|}{$\begin{array}{l}\text { Ethylene production } \\
\qquad\left(\mu \mathrm{l} \cdot \mathrm{kg}^{-1} \cdot \mathrm{h}^{-1}\right)\end{array}$} & \multicolumn{2}{|c|}{$\begin{array}{l}\alpha-\mathbb{I} \text { Famesene } \\
\left(\mathrm{nmol} \cdot \mathrm{cm}^{-2}\right)\end{array}$} & \multicolumn{2}{|c|}{$\begin{array}{l}\text { Conjugated trienes } \\
\quad\left(\mathrm{nmol} \cdot \mathrm{cm}^{-2}\right)\end{array}$} & \multicolumn{2}{|c|}{$\begin{array}{l}\text { Antioxidants } \\
\left(\text { OD } 200 / \mathrm{cm}^{-2}\right)\end{array}$} \\
\hline (weeks) & $\mathrm{O}$ days & 5 days & $\mathrm{O}$ days & 5 days & $\mathrm{O}$ days & 5 days & $\mathrm{O}$ days & 5 days \\
\hline o & 0.06 & 0.07 & 0.1 & 1.1 & 0.11 & 0.07 & 0.2 & 0.3 \\
\hline 2 & 0.5 & 68 & 1.4 & 24.1 & 0.12 & 0.27 & 0.2 & 0.9 \\
\hline 4 & 11 & 127 & 15.0 & 54.8 & 0.27 & 1.17 & 0.5 & 1.9 \\
\hline 6 & 18 & 192 & 30.0 & 54.5 & 0.53 & 1.58 & 0.6 & 2.3 \\
\hline 8 & 30 & 246 & 50.9 & 56.8 & 1.64 & 2.98 & 1.3 & 2.5 \\
\hline 10 & 22 & 220 & 41.4 & 61.3 & 2.50 & 5.15 & 1.1 & 2.2 \\
\hline 12 & 27 & 253 & 48.3 & 63.7 & 2.96 & 6.62 & 1.2 & 2.4 \\
\hline \multicolumn{9}{|l|}{ Significance } \\
\hline Warming (W) & \multicolumn{2}{|c|}{$* *$} & \multicolumn{2}{|c|}{$* * *$} & \multicolumn{2}{|c|}{$* * *$} & \multicolumn{2}{|c|}{$* * *$} \\
\hline Weeks $(\mathrm{T})$ & \multicolumn{2}{|c|}{$* *$} & \multicolumn{2}{|c|}{$* * *$} & \multicolumn{2}{|c|}{$* * *$} & \multicolumn{2}{|c|}{$* * *$} \\
\hline Linear & \multicolumn{2}{|c|}{$* *$} & \multicolumn{2}{|c|}{$* * *$} & \multicolumn{2}{|c|}{$* * *$} & \multicolumn{2}{|c|}{$* * *$} \\
\hline Quadratic & \multicolumn{2}{|c|}{$* *$} & \multicolumn{2}{|c|}{$* * *$} & \multicolumn{2}{|c|}{$* * *$} & \multicolumn{2}{|c|}{$* * *$} \\
\hline $\mathrm{W} \times \mathrm{T}$ & \multicolumn{2}{|c|}{$* *$} & \multicolumn{2}{|c|}{$* * *$} & \multicolumn{2}{|c|}{$* * *$} & \multicolumn{2}{|c|}{$* * *$} \\
\hline
\end{tabular}

\footnotetext{
"*** Significant at $P \leq 0.01$ or 0.001 , respectively.
} 
Table 3. Effects of warming treatments on hexane-extractable compounds in peel of 'Granny Smith' apples after storage at 0C for 25 weeks.

\begin{tabular}{|c|c|c|c|c|}
\hline $\begin{array}{l}\text { Weeks at } 0 \mathrm{C} \\
\text { before warming }\end{array}$ & $\begin{array}{c}\alpha \text {-Farnesene } \\
\left(\mathrm{nmol} \cdot \mathrm{cm}^{-2}\right)\end{array}$ & $\begin{array}{l}\text { Conjugated trienes } \\
\left(\mathrm{nmol} \cdot \mathrm{cm}^{-2}\right)\end{array}$ & $\begin{array}{l}\text { Anti } \\
\text { (OD }\end{array}$ & $\begin{array}{l}\text { ioxidants } \\
\left.200 / \mathrm{cm}^{-2}\right)\end{array}$ \\
\hline o & 3.55 & 4.4 & & 1.14 \\
\hline 2 & 4.82 & 3.8 & & 1.94 \\
\hline 4 & 5.30 & 4.3 & & 2.46 \\
\hline 6 & 4.52 & 3.0 & & 1.72 \\
\hline 8 & 4.65 & 3.3 & & 2.30 \\
\hline 10 & 5.32 & 4.7 & & 2.30 \\
\hline 12 & 4.12 & 4.6 & & 1.86 \\
\hline \multicolumn{5}{|l|}{ Significance } \\
\hline Weeks & $* * *$ & $* * *$ & & $* * *$ \\
\hline Linear & NS & NS & & $*$ \\
\hline Quadratic & $* * *$ & $* * *$ & & $* * *$ \\
\hline Pentic & $*$ & $* *$ & & NS \\
\hline
\end{tabular}

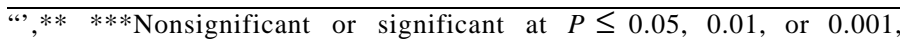
respectively.

ethylene production and extraction with hexane a) before and b) after the 5 days at $20 \mathrm{C}$, and c) after 25 weeks at 0C; 30 for DPA treatment; and 60 (30 warmed and 30 not treated) for evaluation of scald after storage plus 7 days at 20C. The DPA-treated fruit were also evaluated for scald at the same time.

In 1992, two additional experiments were conducted to determine the specificity of warming time and temperature. In the first, five replicate preclimacteric samples harvested on 9 Apr. were stored at $0 \mathrm{C}$ for 2 weeks before transfer to $20 \mathrm{C}$ for between 0 and 14 days, after which they were returned to 0C. At the end of each warming period, internal ethylene concentration and ground color were measured on replicate 10-fruit samples before extraction with hexane. Twenty-five weeks after harvest, all fruit were transferred to 20C, 10 fruit per replicate were tested for firmness after 1 day, and 50 fruit per replicate were evaluated for greasiness and incidence of disorders after 7 days. In the second test, fruit from the same harvest as above were stored at $0 \mathrm{C}$ for up to 4 weeks before transfer to $10 \mathrm{C}$ or $20 \mathrm{C}$ for 5 days, after which they were returned to $0 \mathrm{C}$. At removal and after warming, 10 fruit per replicate were measured for internal ethylene concentration and extracted in hexane. After 25 weeks, all fruit were transferred to 20C. Firmness and background color of 10 fruit were measured after 1 day, and 50 fruit were evaluated for disorders after 7 days.

Effects of conditioning. Fruit were harvested from the same trees and on the same date as in the 1991 warming experiment. Replicates of 80 fruit either were stored immediately at 0C or kept at $10 \mathrm{C}$ (conditioned) for 5 or 10 days before storage at $0 \mathrm{C}$. Ten fruit per replicate were taken for measurement of internal ethylene, background color and extraction in hexane at the end of each conditioning period, and for extraction in hexane after 25 weeks at 0C. The remaining 60 fruit were assessed for scald after 7 days at 20C following storage.

Analytical methods. Most 10-fruit samples were used both for measuring either internal ethylene concentration or ethylene production, and hexane extraction. Internal ethylene concentrations were measured on 1-ml samples of internal gas drawn into a syringe through a hypodermic needle inserted into the core cavity of each fruit. Rates of ethylene production were measured following sealing of two five-fruit samples in 4.5-liter containers for $1 \mathrm{~h}$ followed by analysis of head space gas. Ethylene concentrations were measured by gas chromatography (PU4500 fitted with a flame ionization detector; Philips, England). Background color was assessed using a color reflectance meter (Chroma Meter II; Minolta, Tokyo) under CIE illuminant D65 conditions. Two readings per fruit were taken and the $L^{*}, a^{*}, b^{*}$, and $a^{*} / b^{*}$ values were used to describe the changes in color; for' Granny Smith', $\mathrm{a}^{*}$ / $\mathrm{b}^{*}$ ratios have linear relationships with hue angles over the range of -0.60 to -0.35 (Hirst et al., 1990). The 10 fruit of each replicate then were dipped in about $90 \mathrm{ml}$ of high-performance liquid chromatography (HPLC)-grade hexane for $2 \mathrm{~min}$ and rinsed with fresh hexane. The solutions were made to $100 \mathrm{ml}$, and appropriately diluted aliquots were measured for UV absorbance at 200 $\mathrm{nm}$ for estimation of antioxidant concentration, and $281 \mathrm{~nm}$ and $290 \mathrm{~nm}$ for estimation of conjugated triene concentration (Meir

Table 4. Incidence and severity of superficial scald on 'Granny Smith' apples removed from 0C after 2 to 12 weeks and kept at 20C for 5 days before being returned to $0 \mathrm{C}$, or treated with $1 \mathrm{~g} \cdot \mathrm{liter}^{-1}$ of diphenylamine (DPA) instead of being warmed. The samples placed in storage at 0 weeks either were treated with DPA or had no treatment applied. Scald was evaluated after 25 weeks of storage plus 7 days at $20 \mathrm{C}$.

\begin{tabular}{|c|c|c|c|c|}
\hline \multirow{2}{*}{$\begin{array}{l}\text { Time of removal } \\
\text { from storage } \\
\text { (weeks) }\end{array}$} & \multicolumn{2}{|c|}{ Warmed } & \multicolumn{2}{|c|}{ DPA-treated } \\
\hline & $\begin{array}{c}\text { Scald } \\
(\%)\end{array}$ & $\begin{array}{c}\text { Scald } \\
\text { severity' }\end{array}$ & $\begin{array}{c}\text { Scald } \\
(\%)\end{array}$ & $\begin{array}{c}\text { Scald } \\
\text { severity }\end{array}$ \\
\hline $\mathrm{o}$ & 97 & 2.7 & 12 & 1.2 \\
\hline 2 & 14 & 0.9 & 32 & 1.2 \\
\hline 4 & 33 & 1.1 & 26 & 0.8 \\
\hline 6 & 28 & 1.1 & 25 & 1.1 \\
\hline 8 & 48 & 1.2 & 43 & 1.1 \\
\hline 10 & 61 & 1.4 & 51 & 1.4 \\
\hline 12 & 77 & 1.6 & 79 & 1.9 \\
\hline \multicolumn{5}{|l|}{ Significance } \\
\hline Treatment $(\mathrm{T})$ & $* *$ & $*$ & & \\
\hline Weeks (W) & $* *$ & $* * *$ & & \\
\hline $\mathrm{T} \times \mathrm{W}$ & $* *$ & $* * *$ & & \\
\hline Warming vs. DPA: & & & & \\
\hline 0 week & $* *$ & $* *$ & & \\
\hline 2 weeks & $* *$ & NS & & \\
\hline 4 to 12 wks & NS & NS & & \\
\hline
\end{tabular}

${ }^{2}$ Visual scale: $0=$ no scald, $1=1 \%$ to $10 \%, 2=11 \%$ to $33 \%, 3=34 \%$ to $66 \%, 4=67 \%$. to $100 \%$. of surface affected. Ns, $, \cdots, \cdots+\cdots$ Nonsignificant or significant at $P \leq 0.05,0.01$, or 0.001 , respectively. 
Table 5. Effects of warming 'Granny Smith' apples for different times at $20 \mathrm{C}$ after 2 weeks at $0 \mathrm{C}$. Ethylene, $\boldsymbol{\alpha}-\mathbf{1}$ famesene, and conjugated trienes (CT) were measured at the end of warming. After 25 weeks at $0 \mathrm{C}$, fruit were transferred to 20C; color, greasiness and firmness were measured after 1 day, and disorders after 7 days.

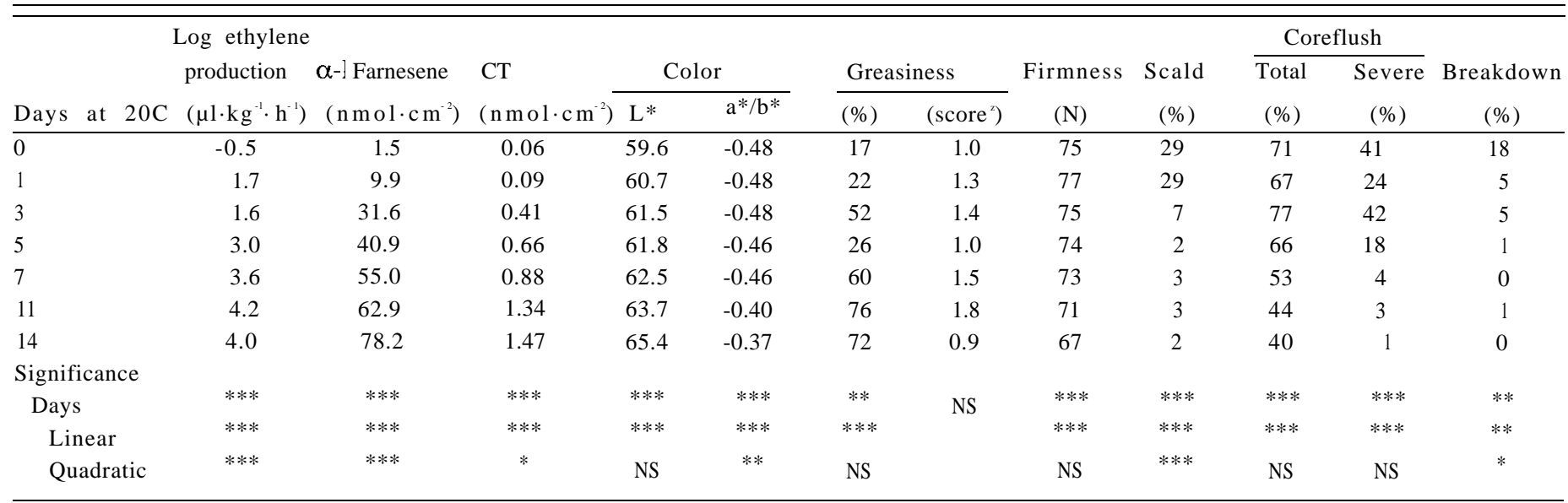

${ }^{2}$ Score: 1 = slight; 2 = moderate; $3=$ severe.

${ }^{\mathrm{NS}, *, * *,{ }^{* * *}}$ Nonsignificant or significant at $P \leq 0.05,0.01$ or 0.001 , respectively.

and Bramlage, 1988). Aliquots also were passed through florisil (Huelin and Coggiola, 1968) and absorbance at $232 \mathrm{~nm}$ was used to estimate $\alpha$-farnesene concentration in the extracts. Fruit surface area was calculated using weight and density of fruit, assuming that each fruit approximated a sphere (Watkins et al., 1988). Data are expressed as nanomoles per square centimeter of peel.

Scald was recorded as percent incidence and severity on affected fruit using a scale where $0=$ none, $1=1 \%$ to $10 \%, 2=11 \%$ to $33 \%, 3=34 \%$ to $66 \%$, and $4=67 \%$ to $100 \%$ of the surface area affected. Greasiness was recorded as percent incidence and also as severity by touching each fruit and rating it using a scale where 1 = slight, $2=$ moderate, and $3=$ severe. Severity ratings for scald and greasiness were obtained by dividing the total score only by the number of fruit affected. Firmness was measured on opposite sides of pared fruit using an EPT- 1 pressure tester (Lake City Technical Products, Canada) fitted with an 11.1-mm-diameter Effigi tip.

\section{Results}

Effects of storage temperature. During storage at 0 to $20 \mathrm{C}$, ethylene production and $\boldsymbol{\alpha}$-farnesene and antioxidant concentration patterns showed similar trends at a given temperature (Fig. 1 $\mathrm{A}, \mathrm{B}$, and D). For all three variables, levels at 4 and $10 \mathrm{C}$ were higher than at other temperatures. Regressions of $\boldsymbol{\alpha}$-farnesene and antioxidant concentrations against ethylene production provided $r^{2}$ values of 0.67 and $0.63(P<0.001, \mathrm{n}=150)$, respectively. In contrast, changes in conjugated triene concentrations at the various temperatures were distinctly different from those of the other substances, with the highest concentrations occurring at 0 and $4 \mathrm{C}$ (Fig. 1C). After storage, injury clearly identifiable as scald only occurred at $0(100 \%)$ and $4 \mathrm{C}(87 \%)$. After storage at $10 \mathrm{C}$, some fruit had browning around the lenticels as well as depressions without discoloration, but no typical scald symptoms.

At the end of storage at each temperature, color measurements were taken as indications of relative senescence of fruit during storage. $\mathrm{L}^{*}$ (lightness) and $\mathrm{a} * / \mathrm{b}^{*}$ (greenness) values indicated that greatest color loss occurred at $15 \mathrm{C}$, and least color loss at $0 \mathrm{C}$, while fruit at 4,10 , and $20 \mathrm{C}$ reached almost the same color during storage (Table 1). Thus, slightly less senescence appeared to have occurred at $0 \mathrm{C}$ for 30 weeks, and slightly more at $15 \mathrm{C}$ for 7.5 weeks, than at the other temperatures. However, these small differences in senescence appear to have had no effect on scald development, since nearly all fruit at 0 and $4 \mathrm{C}$ scalded and no fruit at 15 or $20 \mathrm{C}$ scalded.

Effects of warming. Ethylene production and concentrations of $\alpha$-farnesene, conjugated trienes and antioxidants had increased in fruit kept 2 to 4 weeks at $0 \mathrm{C}$ without warming (Table 2) in patterns similar to those found in fruit at $0 \mathrm{C}$ in the previous experiment (Fig. 1). When fruit were transferred to $20 \mathrm{C}$ for 5 days, ethylene production and hexane-extracted compounds rose sharply (Table 2 ). The increase in ethylene production of fruit that were warmed after 2 weeks at 0C was much greater (135-fold) than that recorded at the other removal times (10-fold), and those for $\alpha$ - - farnesene and antioxidants also were greatest at this time. In contrast, conjugated trienes increased the most (333-fold) during warming after 4 weeks at $0 \mathrm{C}$.

During storage, small but significant increases in $\mathrm{L}^{*}, \mathrm{a}^{*}$, and $\mathrm{b}^{*}$ values of fruit surfaces occurred (data not shown). $\mathrm{L}^{*}$ and $\mathrm{b}^{*}$ values did not change during warming, but $a^{*}$ values became less negative during warming after 2 to 6 weeks (data not shown). Correlations $(n=35)$ between increases in ethylene production and changes in $a^{*} / b^{*}$ values during warming were not significant, indicating that color differences were not the direct result of differences in ethylene production.

After storage, fruit that had been warmed after 2 or more weeks at $0 \mathrm{C}$ contained more $\alpha$-ffarnesene and more antioxidants than those that had been warmed without prior storage at 0C (Table 3). Fruit warmed after 2 to 8 weeks at $0 \mathrm{C}$ generally contained less conjugated trienes than those warmed without storage or after 10 or 12 weeks at $0 \mathrm{C}$.

Warming reduced incidence and severity of scald (Table 4). Incidence was reduced the most when fruit were warmed after 2 weeks at $0 \mathrm{C}$, and the effect generally declined with longer time at OC before warming. Reduction of severity was the same when warming occurred any time between 2 and 8 weeks. Treatment with DPA produced results similar to those from warming except that treatment with DPA before storage reduced scald, and after 2 weeks, warming was more effective than DPA.

Subsequent experiments in 1992 tested effects of different times and temperatures of warming. Scald susceptibility was less than in 1991, with maximum incidence being 29\% (Tables 5 and 6). In general, warming at $20 \mathrm{C}$ for 3 days or more gave nearly complete scald control (Table 5) and was about equally effective when applied after 1 to 4 weeks at 0C (Table 6). Response to 
Table 6. Effects of time at $0 \mathrm{C}$ before warming and of warming temperature ( 10 or $20 \mathrm{C}$ ) on 'Granny Smith' apples. Ethylene, $\alpha$-farnesene, and conjugated trienes (CT) were measured before and after warming. After 25 weeks at $0 \mathrm{C}$ fruit were transferred to $20 \mathrm{C}$; firmness was measured after 1 day and disorders were recorded after 7 days.

\begin{tabular}{|c|c|c|c|c|c|c|c|c|c|}
\hline \multirow{2}{*}{$\begin{array}{l}\text { Time at } 0 \mathrm{C} \\
\text { berore warming } \\
\text { (weeks) }\end{array}$} & \multicolumn{3}{|c|}{$\begin{array}{l}\text { Log ethylene production } \\
\left(\mu \mathrm{l} \cdot \mathrm{kg}^{-1} \cdot \mathrm{h}^{-1}\right)\end{array}$} & \multicolumn{3}{|c|}{$\begin{array}{l}\alpha \text {-Farnesene } \\
\left(\mathrm{nmol} \cdot \mathrm{cm}^{-2}\right)\end{array}$} & \multicolumn{3}{|c|}{ CT $\left(\mathrm{nmol} \cdot \mathrm{cm}^{-2}\right)$} \\
\hline & Before & After $10 \mathrm{C}$ & After $20 \mathrm{C}$ & Before & After $10 \mathrm{C}$ & After $20 \mathrm{C}$ & Before & After $10 \mathrm{C}$ & After $20 \mathrm{C}$ \\
\hline 0 & -1.0 & -1.4 & -1.7 & 2.5 & 1.0 & 3.6 & 0.1 & 0.2 & 0.1 \\
\hline 1 & -1.6 & 0.1 & 0.8 & 0.8 & 17.1 & 24.2 & 0.1 & 0.4 & 0.4 \\
\hline 2 & -0.3 & 0.6 & 1.1 & 1.4 & 34.3 & 42.8 & 0.1 & 0.6 & 0.4 \\
\hline 3 & 0.1 & 0.6 & 1.4 & 5.1 & 50.0 & 50.6 & 0.1 & 0.5 & 0.7 \\
\hline 4 & 0.5 & 0.9 & 1.4 & 7.7 & 46.4 & 60.6 & 0.1 & 0.5 & 0.8 \\
\hline \multicolumn{10}{|l|}{ Significance } \\
\hline Time before Warming (T) & & $* * *$ & & & $* * *$ & & & $* * *$ & \\
\hline Linear & & $* * *$ & & & $* * *$ & & & $* * *$ & \\
\hline Quadratic & & $* * *$ & & & $* * *$ & & & NS & \\
\hline Cubic & & NS & & & $* * *$ & & & NS & \\
\hline Temp $\left({ }^{\circ} \mathrm{C}\right)$ & & $* * *$ & & & $* * *$ & & & $* * *$ & \\
\hline $\mathrm{T} \times \mathrm{C}$ & & $* * *$ & & & $* * *$ & & & $* * *$ & \\
\hline
\end{tabular}

${ }^{2}$ Severe coreflush only. Total coreflush was not significantly affected by treatments in this experiment.

${ }_{\mathrm{NS}, *, * * * * * *}$ Nonsignificant or significant at $P 0.05,0.01$, or 0.001 , respectively.

warming at $10 \mathrm{C}$ was not significantly different from that at $20 \mathrm{C}$ (Table 6). Keeping fruit for increasing periods of time at 20C after 2 weeks of storage at $0 \mathrm{C}$ also reduced coreflush and flesh breakdown (Table 5). The extent of reduction of severe coreflush and breakdown was affected by time at $0 \mathrm{C}$ before warming (Table 6). Warming temperature did not affect reduction of severe coreflush, but 20C was slightly better than 10C for reducing breakdown (Table 6).

During warming, ethylene concentrations in fruit increased, more so at $20 \mathrm{C}$ than $10 \mathrm{C}$, the increase being greater with longer time at $\mathrm{OC}$ before warming (Table 6) and with longer warming time (Table 5). Both $\alpha$-farnesene and conjugated trienes increased in fruit peel during warming, increases being greater with longer time at $0 \mathrm{C}$ before warming (Table 6), higher warming temperature (Table 6) and longer warming time (Table 5). At the end of storage, warming usually resulted in measurable decreases in fruit firmness if fruit were warmed for 5 or more days (Tables 5 and 6). Warming also increased incidence of greasy fruit (but not greasiness score) (Table 5) and caused some loss of green color (Table 7) at the end of storage.

Effects of conditioning. When fruit were conditioned at $10 \mathrm{C}$ before storage, no significant changes in $\alpha-1$ farnesene, conjugated trienes or antioxidants occurred during 5 or 10 days and no measurable differences existed after 25 weeks at 0C (data not shown). Nearly all of these fruit developed severe scald after storage.

\section{Discussion}

The storage temperature and warming experiments provide clear evidence that superficial scald can be induced by chilling. Injury symptoms that are typical of scald occurred after prolonged storage of 'Granny Smith' at 0 or $4 \mathrm{C}$, but not after storage at 10, 15, or $20 \mathrm{C}$ for times that produced generally equivalent changes in ground color. The slight injury observed at 10C, which was distinct from typical superficial scald, may be similar to that observed at $15 \mathrm{C}$ by Huelin and Coggiola (1970a). Amelioration of scald by warming (Tables 4, 5, and 6) is characteristic of fruit chilling injuries (Wang, 1993). Chilling injury is viewed as a two-stage event, where rapid damage-inducing events are separated from symptom development events which involve cellular degeneration (Raison and Orr, 1990). Effects of warming meet this criterion since warming altered chemical composition immediately (Tables 2, 5, and 6) but affected scald development many weeks later (Tables 4,5, and 6).

Warming clearly reversed an effect of low temperature, since keeping fruit at $10 \mathrm{C}$ for 5 or 10 days before storage did not reduce scald (data not shown), but warming at 20C after 14 (Tables 4 and 5) or 7 (Table 6) days at $0 \mathrm{C}$ did reduce it. More than 1 day at $20 \mathrm{C}$ was required for reversal (Table 5), and a temperature lower than 20C was effective, although a longer time might be required for consistent results at a lower temperature (Table 6). Smith (1959) used single 5-day warming periods at between 2 and 30 weeks at 0C for 'Bramley's Seedling' apples, and obtained maximum scald reduction from warming at 16 and 20 weeks. The timing of maximum effect of warming therefore was quite different from that on 'Granny Smith' (Table 4), so different cultivars may respond distinctly to warming regimes.

Incidence of coreflush, a recognized chilling disorder in apples (Bramlage and Meir, 1990), also was reduced by warming (Tables 5 and 6). Near elimination took a longer warming time than for scald (Table 5) and this was not as consistent a response as the effect on scald (Table 6). Breakdown of fruit was reduced to about the same extent as scald (Tables 5 and 6), so this disorder also may be chilling-related.

Within the a-farnesene hypothesis of scald development (Anet, 1972), treatments that inhibit scald should lower $\alpha$-farnesene production, inhibit $\boldsymbol{\alpha}$-farnesene oxidation to conjugated trienes, or condition fruit tissues against injury by these products. In our study, higher storage temperatures and warming treatments consistently raised $\alpha$-ffarnesene concentrations in fruit peel during treatment and at the end of storage, but reduced scald. This reinforces the view (Huelin and Coggiola, 1970b) that $\alpha$-1 farnesene itself does not cause scald. $\alpha$-Farnesene accumulation may have been promoted by the high ethylene concentrations that formed in fruit at higher temperatures (Watkins et al., 1993).

Conjugated trienes also increased during warming (Table 2). $\mathrm{Du}$ and Bramlage (1994) presented evidence that $\boldsymbol{\alpha}$-farnesene oxidation in apples produced scald-inducing and nonscald-inducing species of presumed conjugated trienes. Du (1993) also showed that $20 \mathrm{C}$ favored the noninducing species of conjugated trienes while $0 \mathrm{C}$ favored the inducing species. The conjugated trienes reported here, measured at $281 \mathrm{~nm}$, are the presumed scald- 


\begin{tabular}{|c|c|c|c|c|c|c|c|}
\hline \multicolumn{2}{|c|}{$\begin{array}{c}\text { Firmness } \\
\text { (N) }\end{array}$} & \multicolumn{2}{|c|}{$\begin{array}{c}\text { Scald } \\
(\%)\end{array}$} & \multicolumn{2}{|c|}{$\begin{array}{l}\text { Core-flush } \\
\text { (\%) }\end{array}$} & \multicolumn{2}{|c|}{$\begin{array}{c}\text { Breakdown } \\
(\%)\end{array}$} \\
\hline $10 \mathrm{C}$ & $20 \mathrm{C}$ & $10 \mathrm{C}$ & $20 \mathrm{C}$ & $10 \mathrm{C}$ & $20 \mathrm{C}$ & $10 \mathrm{C}$ & 200 \\
\hline 75 & 76 & 27 & 26 & 29 & 31 & 16 & 14 \\
\hline 76 & 74 & 13 & 0 & 25 & 32 & 11 & 3 \\
\hline 75 & 76 & 8 & 2 & 12 & 10 & 4 & 3 \\
\hline 72 & 74 & 6 & 5 & 32 & 9 & 3 & 0 \\
\hline 72 & 73 & 4 & 3 & 24 & 14 & 10 & 1 \\
\hline \multicolumn{2}{|c|}{$P<0.07$} & \multicolumn{2}{|c|}{$* *$} & \multicolumn{2}{|c|}{$*$} & \multicolumn{2}{|c|}{$* *$} \\
\hline \multicolumn{2}{|c|}{ * } & \multicolumn{2}{|c|}{$* *$} & \multicolumn{2}{|c|}{ * } & \multicolumn{2}{|c|}{$* *$} \\
\hline \multicolumn{2}{|c|}{ NS } & \multicolumn{2}{|c|}{$*$} & \multicolumn{2}{|c|}{ NS } & \multicolumn{2}{|c|}{$* *$} \\
\hline \multicolumn{2}{|c|}{ NS } & \multicolumn{2}{|c|}{ NS } & \multicolumn{2}{|c|}{ NS } & \multicolumn{2}{|c|}{ NS } \\
\hline \multicolumn{2}{|c|}{ NS } & \multicolumn{2}{|c|}{ NS } & \multicolumn{2}{|c|}{ NS } & \multicolumn{2}{|c|}{$*$} \\
\hline \multicolumn{2}{|c|}{ NS } & \multicolumn{2}{|c|}{ NS } & \multicolumn{2}{|c|}{ NS } & \multicolumn{2}{|c|}{ NS } \\
\hline
\end{tabular}

Table 7. Effects of time at $0 \mathrm{C}$ before warming and of warming temperature on surface color of' Granny Smith' apples after storage for 25 weeks at $0 \mathrm{C}$.

\begin{tabular}{|c|c|c|c|c|c|}
\hline $\begin{array}{l}\text { Time at } 0 \mathrm{C} \\
\text { before warming }\end{array}$ & $\begin{array}{c}\text { Warming } \\
\text { temp }\end{array}$ & $\mathrm{L}^{*}$ & $a^{*}$ & $b^{*}$ & $a^{*} / b^{*}$ \\
\hline$\overline{0}$ & $10 \mathrm{C}$ & 58.4 & -0.194 & 0.399 & -0.49 \\
\hline 1 & & 59.6 & -0.195 & 0.410 & -0.48 \\
\hline 2 & & 60.3 & -0.199 & 0.418 & -0.48 \\
\hline 3 & & 61.4 & -0.204 & 0.424 & 4.47 \\
\hline 4 & & 60.5 & -0.200 & 0.423 & -0.48 \\
\hline 0 & $20 \mathrm{C}$ & 59.7 & -0.198 & 0.411 & -0.48 \\
\hline 1 & & 62.2 & -0.197 & 0.440 & 4.45 \\
\hline 2 & & 61.7 & -0.205 & 0.433 & -0.47 \\
\hline 3 & & 62.2 & -0.201 & 0.435 & -0.46 \\
\hline 4 & & 61.4 & -0.201 & 0.424 & -0.48 \\
\hline \multicolumn{6}{|l|}{ Significance } \\
\hline Time before warming $(\mathrm{T})$ & & $* * *$ & $* * *$ & $* * *$ & $* *$ \\
\hline Linear & & $* * *$ & $* * *$ & $* * *$ & NS \\
\hline Quadratic & & $* *$ & $* *$ & $* * *$ & $*$ \\
\hline Cubic & & NS & $* *$ & NS & $*$ \\
\hline Quartic & & NS & NS & NS & $*$ \\
\hline Temp $\left({ }^{\circ} \mathrm{C}\right)$ & & $*$ & NS & $* *$ & NS \\
\hline $\mathrm{T} \times \mathrm{C}$ & & NS & NS & $* *$ & $* * *$ \\
\hline
\end{tabular}

inducing species. In our experiments, warming did not reduce scald unless fruit were first stored at 0C (Tables 4 and 6). While the conjugated trienes increased during warming (Tables 2,5, and 6), they were lower at the end of storage (when scald was developing) in the warming treatments that produced the most scald reduction (Table 3). Thus, warming may have induced events that gradually suppressed accumulation of scald-inducing conjugated trienes during long-term storage. However, as time at $0 \mathrm{C}$ before warming increased the effect of warming on the induction on scald was diminished (Table 4). Furthermore, conjugated trienes at the end of storage were not suppressed (Table 3). This indicates that conjugated triene accumulation could not be suppressed after extensive exposure to 0C. DPA, which suppresses accumulation of the scald-inducing conjugated trienes (Du and Bramlage, 1994), also had diminishing effects on scald development as chilling time increased (Table 4).
High storage temperatures (Fig. 1 D) and warming during storage (Table 2) increased 0D $200 \mathrm{~nm}$ values of peel extracts. A number of antioxidants have absorption maxima near $200 \mathrm{~nm}$ (Anet, 1974), and these values correlated strongly with assays of lipid-soluble antioxidant activity of apple peel extracts (Meir and Bramlage, 1988). While the results suggest that higher temperatures and warming may have reduced the formation of conjugated trienes by increasing endogenous antioxidants, Barden and Bramlage (1994b) found that OD $200 \mathrm{~nm}$ values can increase with fruit ripening without corresponding increases in the principal lipid-soluble antioxidants in fruit peel. Therefore, the OD $200 \mathrm{~nm}$ values recorded in peel extracts may not be reliable indices of antioxidant concentrations.

Rather than simply modifying $\alpha$-farnesene oxidation, warming also may have conditioned fruit tissue against damage from injurious products generated at low temperature. Antioxidants 
such as DPA can maintain a high degree of fatty acid unsaturation in fruit during chilling (Wang and Baker, 1979), and synthesis of unsaturated fatty acids may occur during warming (Wang, 1993). Since benefits from both warming and DPA diminished as time at OC before treatment increased (Table 4), increasing amounts of cell damage from longer periods of chilling may either have inhibited this conditioning or rendered it less beneficial. Higher metabolic activity during warming also may remove toxic or inhibitory substances that accumulate at low temperature, or replenish deficiencies that have occurred (Wang, 1993). Perhaps longer warming times are needed as preceding chilling time increases.

An interesting issue is raised by the different stimulations of ethylene production by warming after different periods at $0 \mathrm{C}$ (Table 2). After 2 weeks at 0C, ethylene production was still low but it was stimulated 135-fold during warming. At subsequent removals initial rates of ethylene production were much higher, but they increased only 10 -fold during warming. $\alpha$ - Farnesene and conjugated triene accumulations, in proportion to ethylene production rates, were far greater at $0 \mathrm{C}$ than they were at $20 \mathrm{C}$ (Table 2). Ethylene-stimulated ripening and metabolism in the cold might result in metabolic imbalances that can lead to cell damage, and be different from that at higher temperatures which might condition fruit tissues against cell damage.

Conditioning fruit at $10 \mathrm{C}$ for up to 10 days before storage did not influence scald susceptibility, but during this time, no significant increase in internal ethylene concentration was observed. Initiation of the climacteric in 'Granny Smith' apples is delayed at higher temperatures (Jobling et al., 1991). We propose that if the climacteric had been initiated during the time at $10 \mathrm{C}$, then scald may have been reduced by conditioning. Further experiments are in progress to test this hypothesis. However, the failure of conditioning to reduce scald (data not shown) shows clearly that postharvest conditioning at $10 \mathrm{C}$ is not equivalent to preharvest exposure to temperatures of $10 \mathrm{C}$ or below, in which as few as 100 $\mathrm{h}$ can reduce scald susceptibility of preclimacteric fruit (Barden and Bramlage, 1994a).

Warming maybe an effective nonchemical scald control method for 'Granny Smith' apples, and may have commercial implications for fruit that are not stored under controlled atmospheres. While some loss of fruit quality by ripening maybe a risk associated with warming (Tables 5, 6, and 7), some of our treatments greatly reduced scald with only minor effects on ground color or flesh firmness. Whether similar results occur for cultivars with higher rates of ethylene production remains to be determined.

\section{Literature Cited}

Anet, E. F.L.J. 1972. Superficial scald, a functional disorder of stored apples. IX. Effect of maturity and ventilation. J. Sci. Food Agr. 23:763-769.

Anet, E. F.L.J. 1974. Superficial scald, a functional disorder of stored apples. Xl. Apple antioxidants. J. Sci. Food Agr. 25:299-304.

Anet,E.F.L.J.andI.M.Coggiola.1974,.Supertfcialscald,afunctionaldisorderofstored apples.X.Controløf farneseneautoxidation.J.sci.FoodAgr.25:293-298

Bain, J.M. and F.J. Mercer. 1963. The submicroscopic cytology of superficial scald, a physiological disease of apples. Austral. J. Biol. Sci. 16:442-449.

Barden, C.L. and W.J. Bramlage. 1994a. Separating the effects of low temperature, ripening, and light on loss of scald susceptibility in apples before harvest. J. Amer. Soc. Hort. Sci. 119:54-58

Barden, C.L. and W.J. Bramlage. 1994b. Accumulation of antioxidants in apple peel as related to preharvest factors and superficial scald susceptibility of the fruit. J. Amer. Soc. Hort. Sci. 119:264-269.

Bramlage, W.J. and S. Meir. 1990. Chilling injury of crops of temperate origin, p. 37-49. In: C.Y. Wang (cd.). Chilling injury of horticultural crops. CRC Press,
Boca Raton, Fla.

Brooks, C. and J.S. Cooley. 1917. Effect of temperature aeration and humidity on Jonathan-Spot and scald of apples in storage. J. Agr. Res. $11: 287-318$.

Brooks, C., J.S. Cooley, and D.F. Fisher. 1919. Nature and control of apple scald. J. Agr. Res. 18:211-240.

Chen, P. M., K.L. Olsen, and M. Meheriuk. 1985. Effect of low-oxygen atmosphere on storage scald and quality preservation of 'Delicious' apples. J. Amer. Soc. Hort. Sci. 110:16-20.

Du, Z. 1993, Investigation of peroxidation-associated processes involved in senescence and superficial scald of apples (Malus domestics Borkh.). PhD diss. Univ. of Mass., Amherst.

Du, Z, and W.J. Bramlage, 1994. Roles of ethylene in the development of superficial scald in 'Cortland' apples. J. Amer. Soc. Hort. Sci. 119:516-523.

Hirst, P. M., D.S. Tustin, and I.J. Warrington. 1990. Fruit colour responses of 'Granny Smith' apple to variable light environments. N.Z. J. Crop Hort. Sci. 18:205-214.

Huelin, F.E. and LM. Coggiola, 1968. Superficial scald, a functional disorder of stored apples. IV. Effect of variety, maturity, oiled wraps and diphenylamine on the concentration of $\alpha$ - famesene in the fruit. J. Sci. Food Agr. 19:297-301.

Huelin, F.E. and LM. Coggiola. 1970a. Superficial scald, a functional disorder of stored apples. VI. Evaporation of $\alpha$-farnesene from the fruit. J. Sci. Food Agr. 21:82-86.

Huelin, F.E. and I.M. Coggiola. 1970b. Superficial scald, a functional disorder of stored apples. VII. Effect of applieda-ffamesene, temperature and diphenylamine on scald and the concentration and oxidation ofo-farnesene in the fruit. J. Sci. Food Agr. 21:584-589.

Jobling, J., W.B. McGlasson, and D.R, Dilley. 1991. Induction of ethylene synthesizing competency in Granny Smith apples by exposure to low temperature in air, Postharvest Biol. Technol. 1:111-118.

Kidd, F and C. West, 1935. The cause and control of superficial scald of apples. G.B. Dept. Sci. Ind. Res. Food Investigation Board Rpt. (1934): 111-117.

Lau, O.L. 1990. Efficacy of diphenylamine, ultra-low oxygen, and ethylene scrubbing on scald control in 'Delicious' apples. J. Amer. Soc. Hort. Sci. 115:959-961.

Lurie, S., J.D. Klein, and R. Ben Arie. 1991. Prestorage heat treatment delays development of superficiail scald on 'Granny Smith' apples. HortScience 26:166-167.

Martin, D. and T.L. Lewis. 1961, Scald. Bul. Inst. Intl. Froid, Annexe 1961-1:201206.

Meigh, D.F. 1970. Apple scald, p.556-569. In: A.C. Hulme (cd.). The biochemistry of fruits and their products. Academic Press, London.

Meigh, D.F. and A.A.E. Filmer. 1969, Natural skin coating of the apple and its influence on scald in storage. $\left.11 \boldsymbol{\alpha}_{-}\right]$Farnesene. J. Sci. Food Agr. 20:139-1 43.

Meir, S. and W.J. Bramlage. 1988. Antioxidant activity in 'Cortland' apple peel and susceptibility y to superficial scald after storage. J. Amer. Soc. Hort. Sci. 113:412418.

Padfield, C.A.S. 1949. The effect of periods of pre-storage delay on the groundcolour and cool-storage disorders of Granny Smith apples. I. Superficial scald. N.Z. J. Sci. Tech. Section A 31:40-48.

Raison, J.K. and G.R. Orr. 1990. Proposals for a better understanding of the molecular basis of chilling injury, p. 145-164. In: C.Y. Wang (cd.). Chilling injury of horticultural crops. CRC Press, Boca Raton, Fla.

Sakveit, M.E. and L.L. Morns. 1990. Overview of chilling injury of horticultural crops, p. 3-15. In: C.Y. Wang (ed.). Chilling injury of horticultural crops. CRC Press, Boca Raton, Fla.

Scott, K.J., R.B.H. Wills, and W. McBailey. 1980. The action of phorone and other compounds in controlling superfilcial scald of apples. Scientia Hort. 13:9-14.

Smith, W.H. 1959. Control of superficial scald in stored apples. Nature (London) 183:760.

Smock, R.M. 1961. Methods of scald control on the apple. Cornell Univ. Agr. Expt. Sta., Ithaca, N.Y. Bul. 970.

Wang, C.Y. 1993. Approaches to reduce chilling injury of fruits and vegetables. Hort. Rev. 15:63-95.

Wang, C.Y. and J.E. Baker. 1979. Effects of two free radical scavengers and intermittent warming on chilling injury and polar lipid composition of cucumber and sweet pepper fruits. Plant Cell Physiol. 20:243-251.

Watkins, C. B., C.L. Barden, and W.J. Bramlage. 1993. Relationships among alphafarnesene, ethylene production and superficial scald development of apples. Acts Hort. 343: 155-160.

Watkins, C. B., J.E. Harman, and G. Hopkirk. 1988. Effects of lecithin, calcium, and antioxidant formulations on superficial scald and internal breakdown of 'Granny Smith’ apples. N.Z. J. Expt. Agr. 16:55-61. 